\title{
Ghrelin proteolysis by insulin-degrading enzyme
}

David D. Bocach ${ }^{1}$, Kierstin L. Jones ${ }^{2}$, Jonathan M. Bell ${ }^{2}$, Qiuchen Zheng ${ }^{3}$, Noel D. Lazo ${ }^{3}$, Jillian E. Smith-Carpenter ${ }^{2}$ and Benjamin J. Alper ${ }^{{ }^{*}}$

Author affiliations: 1. Sacred Heart University, Fairfield CT USA, 2. Fairfield University, Fairfield CT USA, 3. Clark University, Worcester MA USA

*To whom correspondence should be addressed: Sacred Heart University Department of Chemistry and Physics, 5151 Park Ave. SC105G, Fairfield, CT USA 06825. Phone: 203-396-8105. E-mail: alperb@sacredheart.edu

\section{$\underline{\text { Abstract }}$}

Here we report proteolysis of synthetic acylated human ghrelin by recombinant human insulin-degrading enzyme (IDE). Kinetic parameters and sites of proteolytic cleavage were evaluated. Ghrelin proteolysis by IDE was inhibited by ethylenediaminetetraacetate (EDTA), a metal chelating agent. Ghrelin proteolysis appears at least somewhat specific to M16 family proteases such as IDE, as the M13 protease neprilysin (NEP) did not exhibit ghrelin proteolysis in this study. A quenched fluorogenic peptide substrate comprising the primary sites of IDE-mediated ghrelin proteolysis (McaQRVQQRKESKK(Dnp)-OH; Mca: 7-methoxycoumarin-3-carboxylic acid; Dnp: 2,4-dinitrophenyl) was developed and used to evaluate enzyme specificity and kinetic parameters of proteolysis. Like acyl ghrelin, Mca-QRVQQRKESKK(Dnp)-OH was efficiently cleaved by IDE central to the target sequence. We anticipate that this quenched fluorogenic peptide substrate will be of value to future studies of ghrelin proteolysis by IDE and potentially other peptidases.

\section{Introduction}

Ghrelin is an octanoylated 28 amino acid enteroendocrine hormone involved in mammalian energy homeostasis [Kojima et al. 1999, Tschop et al. 2000, Nakazato et al. 2001, Varela et al. 2011, Müller et al. 2015 and others]. Sartorially named for its role as a growth hormone release (GHREL) factor [Kojima et al. 1999], the peptide is frequently coined a "hunger hormone," as it promotes feeding and control of feeding patterns in humans and rodents [Nakazato et al. 2001, Wren et al. 2001., Asakawa et al. 2001, Cummings et al. 2001, Tschop et al. 2001, Drazen et al. 2006]. As first characterized in rats, ghrelin derives from a $0.62 \mathrm{~kb}$ mRNA transcript [Kojima et al. 1999]. In both humans and rats, the ghrelin gene product yields a 117 amino acid preproghrelin precursor protein, which is subject to extensive post-translational processing by endoproteolytic cleavage and acylation [Kojima et al. 1999].

Post-translational processing of preproghrelin appears to produce at least 2 secreted hormones [Kojima et al. 1999, Zhang et al. 2005; comment in Garg A. 2007]: 1. the mature octanoylated ghrelin (acyl ghrelin), derived from residues 24-51 of preproghrelin and acylated on Ser 3 by ghrelin O-acyltransferase (GOAT) [Kojima et al. 1999, Zhu et al. 2006, Ozawa et al. 2007, Yang et al. 2008, Hougland J. 2019], and 2. obestatin, a C-terminally amidated peptide derived from residues 76-98 of preproghrelin [Zhang et al. 2005] that may be subject to carboxypeptidase E and C-terminal peptidyl alpha-amidating enzyme activities [Ozawa et al. 2007]. Solution-state NMR structural dynamics show that ghrelin association with the growth hormone secretagogue receptor (GHS-R) is dependent on the hormone's N-terminal octanoyl moiety and N-terminal hydrophobic core [Ferre et al. 2019].

A shared axis for ghrelin and insulin signaling in control of glucose metabolism has been put forward [Mani et al. 2019]. Prior studies have shown a role for acyl ghrelin in control of insulin secretion and glucose metabolism [Broglio et al. 2001, Broglio et al. 2004]. In animal models, ghrelin inhibits insulin secretion [Reimer et al. 2003, Dezaki et al. 2004, Salehi et al. 2004, Qader et al. 2005]. In humans, epidemiologic studies have revealed an inverse correlation between ghrelin levels and insulin resistance [Tschöp et al 2001]. Obesity and type 1 diabetes are associated with decreased circulating ghrelin levels [Soriano-Guillén et al. 2004, Martos Moreno et al. 2006], while a single dose of intravenous ghrelin has been shown to increase plasma glucose levels followed by reduction in fasting glucose levels [Broglio et al. 2001], potentially suggesting inhibition of insulin secretion [Müller et al. 2015].

Yet, the metabolic fate of ghrelin remains to be exhaustively characterized. The M13 zinc protease neprilysin (NEP) has been postulated to play a role in ghrelin cleavage on the basis of peptide cleavage products observed in rat serological analysis [De Vriese, 2004 Endocrinology]. However, ghrelin hydrolysis by NEP has not been demonstrated in vivo or in vitro, and it remains to be determined whether a significant fraction of ghrelin is retained in circulation following association with the signaling receptor. 
A role for insulin-degrading enzyme (IDE) in ghrelin proteolysis has not been previously demonstrated. IDE is a member of the M16 subfamily of zinc endopeptidases [Barrett and Rawlings, 2004]. M16 peptidases bear an invariant HXXEH zinc-binding and catalytic motif and are termed inverzincins on the basis of motif sequence inversion relative to the HEXXH consensus motif of M4 (thermolysin) family proteases [Becker and Roth 1992, Barrett and Rawlings, 2004].

Like other M16 peptidases IDE exhibits broad substrate specificity. Established IDE substrates include insulin [Mirsky et al. 1949], glucagon [Baskin et al. 1974], epidermal growth factor and transforming growth factor alpha [Gehm and Rosner, 1991], and other hormones with roles in homeostasis, cell growth, and metabolism [Becker and Roth 1995]. Common structural features of IDE substrates include a capacity for peptides to fit within the enzyme's central binding cavity $\left(\mathrm{M}_{\mathrm{r}}<\sim 10 \mathrm{kDa}\right)$, a tendency to adopt beta strand or beta-turn conformations, and hydrophobic or amyloidogenic character proximal to the site of peptide hydrolysis [Shen et al. 2006, Kurochkin IV, 1998, Stefanidis et al. 2018].

Notably, the budding yeast IDE homologs AxI1p and Ste23p support $\mathrm{N}$-terminal cleavage of a-factor mating pheromone [Adames et al. 1995]. Yeast a-factor is a farnesylated dodecapeptide that is subject to multiple post-translational modifications including $\mathrm{N}$-terminal serine acylation and processive proteolytic cleavage prior to sec-independent export [Michaelis and Herskowitz, 1988; Powers and Michaelis 1986, Michaelis and Barrowman, 2012]. When heterologously expressed in S. cerevisiae, mammalian IDE [Kim et al. 2005], the E. coli M16A homolog pitrilysin [Alper et al. 2006], and the M16C family A. thaliana presequence peptidase PreP [Phillips JE, 2007] all support a-factor cleavage. These observations suggest that a capacity to adopt $\mathrm{N}$-terminally acyl lipidated substrates is a specificity factor conserved among homologs of the M16 subfamily.

Here we demonstrate that recombinant human IDE can degrade synthetic octanoylated human ghrelin in vitro. In comparison with prior work, the observed rate of IDE-mediated ghrelin degradation was comparable or superior to the rate of IDE-mediated degradation of insulin-FITC and recombinant amyloid beta 1-40 peptides [Stefanidis et al. 2018]. Moreover, ghrelin degradation appears at least somewhat specific to M16 peptidases such as IDE, as the catalytically active M13 protease NEP did not exhibit ghrelin proteolysis in this study. Ghrelin degradation by IDE is an iterative process. IDE-mediated ghrelin cleavage sites were identified using HPLC and MALDI-TOF mass spectrometry. IDEmediated ghrelin cleavage sites informed construction of a novel fluorescence-resonance energy transfer (FRET) substrate (Mca-QRVQQRKESKK(Dnp)-OH; Mca: 7-methoxycoumarin; Dnp: 2,4-dinitrophenyl). We anticipate that this substrate may serve as a useful proxy for native ghrelin in future studies of its proteolysis by IDE or other peptidases.

\section{Materials and methods}

\section{Expression and purification of recombinant enzymes}

Isolation of recombinant human IDE, catalytically inactive IDE E111Q, and glutathione S-transferase (GST) were carried out as previously described [Stefanidis et al. 2018]. Amino acid residues $\mathrm{M}_{42}$ through $\mathrm{L}_{1016}$ of the annotated IDE translation products were expressed in bacterial host BL21 DE3 as C-terminal polyhistidine tagged fusion partner (i.e., $\left.I_{\mathrm{IDE}}-\mathrm{L1016}-6 \mathrm{xHis}\right)$. The IDE E111Q mutant was derived from this construct through targeted mutagenesis of the IDE $\mathrm{M}_{\mathrm{M} 42-}$ L1016-6xHis clone, achieved by inverse PCR [Stefanidis et al. 2018]. Construction of the C-terminally polyhistidine tagged S. japonicum GST (i.e., GST-6xHis) has been previously reported [Considine et al. 2017].

Following transformation with the appropriate expression vector, bacterial cultures were grown to high cell density (0.5$1.0 \mathrm{OD}_{600} ; 37^{\circ} \mathrm{C} \times 195 \mathrm{RPM}$ ) and induced for protein expression. Isopropyl-beta-d-thiogalactopyranoside (IPTG) was added to $0.1 \mu \mathrm{M}$, cell culture temperature shifted to $25^{\circ} \mathrm{C}$, and cells harvested following overnight protein induction. Bacterial cell pellets were reconstituted in a lysis/wash buffer compatible with immobilized metal affinity chromatography and lysed by ultrasonic disruption. Insoluble material was cleared from the lysate by centrifugation (3200 $\mathrm{g} \times 20 \mathrm{~min}$. at $4{ }^{\circ} \mathrm{C}$ ). Polyhistidine tagged IDE was isolated from the soluble lysate fraction by immobilized nickel affinity chromatography (NI-IDA resin, Takara Clontech Inc.) in accordance with manufacturer's instructions. Approximately 100 column volumes of lysis/wash buffer were applied following column loading. Buffers were refrigerated or kept on ice throughout the purification procedure. Purified proteins were eluted with $300 \mathrm{mM}$ imidazole, $300 \mathrm{mM} \mathrm{NaCl}$, and $20 \mathrm{mM}$ sodium phosphate $\mathrm{pH} \mathrm{7.4,} \mathrm{and} \mathrm{held} \mathrm{on} \mathrm{ice} \mathrm{while} \mathrm{protein} \mathrm{concentration} \mathrm{was} \mathrm{determined} \mathrm{using}$ the BioRad Protein Assay [Bradford MM, 1976]. Elution products were diluted to $50 \% \mathrm{w} / \mathrm{v}$ glycerol and stored at $-20^{\circ} \mathrm{C}$. 


\section{Commercial sourcing of synthetic human ghrelin and recombinant human neprilysin}

Octanoylated synthetic human ghrelin was purchased from New England Peptide, Inc. (Gardner, MA, USA). Upon receipt, peptide was reconstituted in dimethylsulfoxide (DMSO) to $20 \mathrm{mg} / \mathrm{mL}$, aliquoted and stored at $-20^{\circ} \mathrm{C}$. Recombinant human neprilysin was a gift of ACROBiosystems, Inc. (Newark, DE, USA). Upon receipt as a lyophilized powder, neprilysin was reconstituted to $0.2 \mathrm{mg} / \mathrm{mL}$ by addition of water and stored at $-80^{\circ} \mathrm{C}$.

\section{SDS-PAGE assay for ghrelin proteolysis.}

All proteolytic assays in this study were performed in $50 \mathrm{mM}$ Tris(hydroxymethyl)aminomethane (Tris), $\mathrm{pH} 7.3$ and conducted at $37^{\circ} \mathrm{C}$. Conditions for analysis of IDE-mediated ghrelin proteolysis were similar to those used to evaluate IDE-mediated proteolysis of FITC-labelled insulin and amyloid beta peptides, as described previously [Stefanidis et al. 2018], and elaborated below.

Ghrelin degradation assays were performed after separately assembling pre-mixtures containing $30 \mathrm{ng} / \mu \mathrm{L} I D E, 30 \mathrm{ng} / \mu \mathrm{L}$ neprilysin or $100 \mathrm{ng} / \mu \mathrm{L} \mathrm{GST}$, and $0.5 \mu \mathrm{g} / \mu \mathrm{L}$ substrate (octanoylated ghrelin). Where present for purposes of enzyme inhibition prior to the proteolytic experiment, 500 mM EDTA, an established IDE inhibitor [Kirschner and Goldberg 1983], was added to the enzyme pre-mixture during initial assembly. Enzyme and substrate pre-mixtures were preincubated at assay temperature of $37^{\circ} \mathrm{C}$, and the assay was initiated upon mixing of enzyme and substrate.

Proteolytic reactions were quenched at endpoint by mixing 1:2 with SDS-PAGE sample buffer containing $160 \mathrm{mM}$ Tris, $\mathrm{pH}$ 6.8, $100 \mathrm{mM}$ EDTA, 32\% w/v glycerol, 1.25\% w/v $\beta$-mercaptoethanol and 0.003\% w/v bromophenol blue. Samples were loaded onto an SDS-PAGE gel (BioRad Any kD ${ }^{\text {TM }}$ Mini-PROTEAN ${ }^{\circledR}$ TGX gel, manufacturer's Tris-glycine buffer system) and the gel was electrophoresed immediately after sample loading. Following separation (100 V x $45 \mathrm{~min}$.), gels were stained using colloidal Brilliant Blue G250 according to the method of Candiano et al. [Candiano et al. 2004]. Densitometric analysis was performed using a BioRad Gel Doc imaging station and BioRad Image Lab Version 6 graphical analysis software.

\section{Identification of IDE-mediated ghrelin cleavage sites}

Proteolytic assays were performed in the manner above and quenched at endpoint in accordance with established methods [Stefanidis, 2018]. Ghrelin cleavage product separation by HPLC and analysis by MALDI-ToF, samples was achieved as described below. $45 \mu \mathrm{L}$ of $50 \mathrm{mM}$ Tris, $\mathrm{pH} 7.3$ were added to the quenched proteolysis experiment and samples were injected into the HPLC (Shimadzu, Prominence). Proteolysis products were separated on a Phenomenex Kinetex C-18 analytical column (100 mm x $4.6 \mathrm{~mm}$ ) using a $1 \mathrm{~mL} / \mathrm{min}$ flow rate and a linear gradient of 20 to $60 \%$ acetonitrile over 20 minutes. Ghrelin and the proteolysis products, elution times between minutes 11 and 14 , were collected. The integrated area under the curve for ghrelin and the three proteolysis products was averaged across three runs and plotted for each timepoint. Cleavage sites were confirmed by matrix-assisted laser desorption ionization timeof-flight (MALDI-TOF) mass spectrometry (Shimadzu, Axima Confidence) using $\alpha$-cyano-4-hydroxycinnamic acid (CHCA) matrix in reflectron mode.

\section{Mca-QRVQQRKESKK(Dnp)-OH peptide synthesis}

A ghrelin derivative FRET substrate was developed using similar design principles as previous insulin B chain and amyloid beta derivative peptide FRET substrates (Stefanidis et al, 2018) that included the major IDE-mediated ghrelin cleavage sites. The FRET substrate Mca-QRVQQRKESKK(Dnp)-OH was synthesized on a PS3 peptide synthesizer (Gryos Protein Technologies) on an Fmoc-Lys(Dnp) Wang resin. After the N-terminal glutamine was added, the final Fmoc was removed, and the resin was washed with DMF and DCM and transferred to a fritted syringe (Torviq). 7-methoxycoumarin-3carboxylic acid was added at the $\mathrm{N}$-terminus using standard 2-(1H-benzotriazol-1-yl)-1,1,3,3-tetramethyluronium hexafluorophosphate (HBTU) coupling protocols. The FRET peptide was cleaved from the resin with a $5 \mathrm{~mL}$ TFA/triisopropylsilane/water (95\%/2,5\%/2.5\%) cocktail for two hours at room temperature. The crude peptide product was precipitated in cold diethyl ether, pelleted by centrifugation, and dried in vacuo. The peptide was HPLC purified using C-18 semi-preparative column (XBridge $\mathrm{BEH}$, Waters) with a flow rate of $3 \mathrm{~mL} / \mathrm{min}$ over a linear gradient of $20 \%-$ $60 \%$ B over 20 minutes (Solvent A: 0.1\% TFA in H2O; Solvent B: 100\% acetonitrile) and monitored at $222 \mathrm{~nm}$. The fractions containing the pure peptide were confirmed by MALDI-TOF using CHCA matrix, then combined and lyophilized. 


\section{FRET proteolysis assays}

Mca-QRVQQRKESKK(Dnp)-OH (FRET ghrelin) proteolysis assays were performed essentially as previously described [Stefanidis, 2018], and adapted for use with the peptide developed for this study. In brief, enzyme ( $2 \mathrm{ng} / \mu \mathrm{L})$ and substrate $(40 \mu \mathrm{M})$ pre-mixtures were separately assembled in $50 \mathrm{mM}$ Tris, $\mathrm{pH} 7.3$ and warmed to $37^{\circ} \mathrm{C}$. The proteolytic reaction was initiated by mixing equal parts enzyme and substrate pre-mixtures ( $25 \mu \mathrm{L} \mathrm{each).} \mathrm{Where} \mathrm{indicated,} \mathrm{EDTA}$ was added to the enzyme pre-mixture. Upon initiation of the proteolytic experiment, fluorescence was monitored in real time using a BioTek Synergy HT plate reader (excitation $325 \pm 25 \mathrm{~nm}$, emission $420 \pm 25 \mathrm{~nm}$, gain setting 90). Half-area black polystyrene 96 well microplates (Corning Costar \#3686; Corning Inc., Corning, NY, USA) were used in this study.

Substrate $V$ proteolysis assays were performed as above, alternatively using $20 \mu \mathrm{M}$ FRET substrate in the pre-mixture. Substrate V (Mca-RPPGFSAFK-Dnp; RND systems, Minneapolis, MN, USA) is a quenched-fluorogenic peptide derivative of bradykinin. Use of this peptide has been previously reported for studies of endothelin converting enzyme (ECE-1), IDE, NEP, and other proteases [Johnson et al., 2000, Sharma et al. 2015, and others].

To identify IDE proteolytic cleavage sites in FRET ghrelin, $50 \mu \mathrm{L}$ of a quenching solution containing $500 \mathrm{mM}$ EDTA and $2 \%$ TFA were added to the $50 \mu \mathrm{L}$ enzymatic assay mixture 10 minutes into the proteolysis experiment. Samples were stored at $-80^{\circ} \mathrm{C}$ prior to analysis of peptide cleavage sites by MALDI-TOF mass spectrometry. A $25 \mu \mathrm{L}$ aliquot of the quenched reaction mixture was prepared for MALDI-TOF mass spectrometry with a C18 reverse-phase ZipTip (Millipore) following the manufacturer's protocols. MALDI-TOF was performed using a CHCA MALDI matrix in reflectron mode.

\section{Circular dichroism analysis of IDE substrates}

To investigate the feasibility of using circular dichroism (CD) to obtain kinetic parameters for the IDE-dependent degradation of acyl ghrelin (Ivancic et al., 2018), CD spectra of the substrate in $50 \mathrm{mM}$ Tris pH 7.3 in the absence or presence of 30\% 2,2,2-trifluoroethanol (TFE), a solvent that enhances helix formation in short peptides with intrinsic alpha-helical propensity (Lazo and Downing, 1997), were recorded. To test the effect of TFE on IDE's activity, CD spectra of insulin in the presence of IDE at a substrate:enzyme ratio of 100:1 were also acquired. All spectra were recorded at 37 ${ }^{\circ} \mathrm{C}$ on a JASCO J-815 spectropolarimeter using quartz cuvettes with a path length of $1 \mathrm{~mm}$. Acquisition parameters include wavelength range of 260 to $200 \mathrm{~nm}$ and 4 scans per spectrum with each scan recorded with a $1 \mathrm{~nm}$ bandwidth and a $4 \mathrm{~s}$ averaging time.

\section{$\underline{\text { Results }}$}

Synthetic octanoylated human ghrelin was degraded by recombinant human insulin-degrading enzyme (IDE; Fig. 1). However, ghrelin was not proteolyzed by IDE bearing the inactivating glutamate 111 to glutamine (E111Q) catalytic site point mutation, neprilysin (NEP), or glutathione S-transferase (GST). The molecular weight of ghrelin is $3400 \mathrm{kDa}$. Consistent with peptide degradation by a zinc-dependent metallopeptidase, disappearance of a low MW fragment in the presence of catalytically active IDE was sensitive to and limited by pretreatment of the enzymatic activity with ethylenediaminetetraacetate (EDTA), a metal chelating agent and established IDE inhibitor [Kirschner and Goldberg 1983].

Ghrelin degradation progresses towards completion over time in the presence of IDE, but not in the presence of the catalytically inactive IDE E111Q mutant or NEP (Fig. 2A), consistent with enzyme-mediated proteolysis by active IDE only. Densitometric analysis (Fig. 2B) suggests the specific activity of ghrelin proteolysis by IDE is $7.1 \pm 1.1$ (standard deviation) $\mathrm{nmol} \mathrm{min} \mathrm{mg}^{-1}$ across the first 5 minutes of the experimental time course. By comparison, under similar conditions, the rate of IDE mediated degradation of FITC-labelled insulin was $2.3 \pm 0.1$ (standard error) $\mathrm{nmol} \mathrm{min}^{-1} \mathrm{mg}^{-1}$, while the rate of proteolysis of recombinant human amyloid beta 1-40 was $6.9 \pm 0.1$ (standard error) nmol min ${ }^{-1} \mathrm{mg}^{-1}$ [Stefanidis et al. 2018]. These values reflect the approximate rate of peptide degradation as judged by disappearance of stain intensity. However, they do not account for the rate of individual cleavage events within the multistep, iterative process of IDE mediated peptide degradation.

To examine the order and location of ghrelin cleavage sites targeted by IDE, peptide hydrolysis was evaluated by HPLC and MALDI-TOF (Fig. 3). Ghrelin proteolysis by IDE appears processive, with initial cleavage sites between residues Q13/ Q14, Q14/R15 and possibly Q10/R11 preceding later cleavage events (chromatograms in Fig. 3A and 3B). The proteolysis 
products resulting from cleavage between Q14/R15 and Q13/Q14 increase rapidly in the first 20 minutes of the proteolytic assays and then plateau or decrease for the Q13/Q14 and Q14/R15 sites, respectively; however, there is a lag in appearance of the third cleavage site between Q10/R11 (Fig. 3C). Further analysis is required to confirm whether the Q10/R11 proteolytic product is produced after initial Q14/R15 and Q13/Q14 cleavage.

Experimentally determined proteolytic cleavage sites informed construction of the Mca-QRVQQRKESKK(Dnp)-OH internally quenched fluorogenic peptide (FRET ghrelin; Fig. 4). This peptide contains amino acid residues immediately Nand C-terminal to the predominant IDE-mediated ghrelin cleavage sites at Q13/Q14 and Q14/R15 (Fig. 4A; grey arrows). Mca-QRVQQRKESKK(Dnp)-OH synthesis was performed using standard solid-phase peptide chemistry, purified by HPLC (Fig. 4B), and verified by MALDI-TOF (Fig. 4C). Proteolysis of FRET ghrelin by IDE was confirmed by real time fluorogenic assay (Fig. 4D). Like the full length acylated hormone, proteolysis of FRET ghrelin was attenuated upon addition of EDTA to the catalytically active enzyme. Mca-QRVQQRKESKK(Dnp)-OH peptide cleavage sites were determined to be similar to those determined for acyl ghrelin, occurring at positions homologous to residues at Q13/Q14 and Q14/R15 of the fulllength peptide hormone (Fig. 4E). Proteolysis of FRET ghrelin by IDE was enzyme-specific, as the was peptide cleaved more rapidly by an equivalent amount of IDE relative to NEP (Fig. 4C), despite NEP exhibiting superior proteolytic activity towards the bradykinin derivative Substrate V (Mca-RPPGSFAFK-Dnp; Fig. 4F).

Efforts to investigate the kinetics of ghrelin proteolysis by IDE using circular dichroism were unsuccessful. Ghrelin bears significant alpha-helical in 30\% TFE (Fig. 5A) but appears largely unstructured in the $50 \mathrm{mM}$ Tris pH 7.3 proteolysis buffer used throughout this study (Fig. 5B). IDE does not degrade insulin in 30\% TFE (Fig. 5C), despite retaining significant insulin degradation activity in $50 \mathrm{mM}$ Tris $\mathrm{pH} 7.3$ proteolysis buffer as indicated by the loss of helical dichroic signal at $222 \mathrm{~nm}$ (Fig. 5D; see also Ivancic et al., 2018). Liquid chromatography (LC) analysis of the insulin + IDE proteolysis experiment performed in 30\% TFE did not provide evidence of peaks corresponding with proteolytic cleavage fragments, consistent with inactivity of IDE in $30 \%$ TFE solvent (not shown). Further work may therefore be warranted to adapt CD for investigation of ghrelin proteolysis.

\section{Discussion}

We have provided the first evidence for ghrelin proteolysis by insulin-degrading enzyme (IDE). This study expands the in vitro specificity of human IDE to include $\mathrm{N}$-terminally acyl-lipidated peptides with hydrophobic amino acid moieties. Consistent with a role for IDE as an important regulator of cell energy homeostasis, demonstration of the capacity for ghrelin proteolysis by IDE adds to an expanding group of peptide substrates that includes insulin [Mirsky et al. 1949], glucagon [Baskin et al. 1974], epidermal growth factor and transforming growth factor alpha [Gehm and Rosner, 1991], and others. The physiological significance, if any, of IDE-mediated ghrelin proteolysis remains to be investigated. In keeping with established roles of yeast M16A homologs Axl1p and Ste23p in proteolytic processing and export of yeast a-factor mating pheromone [Adames et al. 1995,] an intriguing possibility is that IDE may support N-terminally acyllipidated peptide hormone maturation, export and ultimately degradation in mammals and other higher eukaryotes.

\section{Acknowledgements}

This work was supported by funding from Sacred Heart University College of Arts and Sciences, Department of Chemistry and Physics to BJA and DDB. This work was also supported by National Science Foundation Grant CHE-1624774 to JES-C, for which BJA served as contributor, and by a National Institutes of Health Grant R15AG055043 to NDL. Recombinant human neprilysin was a gift from ACROBiosystems, Inc. (Newark, DE, USA). BJA thanks James L. Hougland (Syracuse University, Syracuse, NY) for correspondence and scientific insight, and Walter K. Schmidt, Jr. (University of Georgia, Athens, GA) for continuing correspondence and mentorship. 


\section{References}

1. Kojima M, Hosoda H, Date Y, Nakazato M, Matsuo H, Kangawa K. Ghrelin is a growth-hormone-releasing acylated peptide from stomach. Nature. 1999 Dec 9;402(6762):656-60. doi: 10.1038/45230. PMID: 10604470.

2. Tschöp M, Smiley DL, Heiman ML. Ghrelin induces adiposity in rodents. Nature. 2000 Oct 19;407(6806):908-13. doi: 10.1038/35038090. PMID: 11057670.

3. Nakazato M, Murakami N, Date Y, Kojima M, Matsuo H, Kangawa K, Matsukura S. A role for ghrelin in the central regulation of feeding. Nature. 2001 Jan 11;409(6817):194-8. doi: 10.1038/35051587. PMID: 11196643.

4. Varela L, Vázquez MJ, Cordido F, Nogueiras R, Vidal-Puig A, Diéguez C, López M. Ghrelin and lipid metabolism: key partners in energy balance. J Mol Endocrinol. 2011 Feb 15;46(2):R43-63. doi: 10.1677/JME-10-0068. PMID: 21169422.

5. Müller TD, Nogueiras R, Andermann ML, Andrews ZB, Anker SD, Argente J, Batterham RL, Benoit SC, Bowers CY, Broglio F, Casanueva FF, D'Alessio D, Depoortere I, Geliebter A, Ghigo E, Cole PA, Cowley M, Cummings DE, Dagher A, Diano S, Dickson SL, Diéguez C, Granata R, Grill HJ, Grove K, Habegger KM, Heppner K, Heiman ML, Holsen L, Holst B, Inui A, Jansson JO, Kirchner H, Korbonits M, Laferrère B, LeRoux CW, Lopez M, Morin S, Nakazato M, Nass R, Perez-Tilve D, Pfluger PT, Schwartz TW, Seeley RJ, Sleeman M, Sun Y, Sussel L, Tong J, Thorner MO, van der Lely AJ, van der Ploeg LH, Zigman JM, Kojima M, Kangawa K, Smith RG, Horvath T, Tschöp MH. Ghrelin. Mol Metab. 2015 Mar 21;4(6):437-60. doi: 10.1016/j.molmet.2015.03.005. PMID: 26042199; PMCID: PMC4443295.

6. Wren AM, Seal LJ, Cohen MA, Brynes AE, Frost GS, Murphy KG, Dhillo WS, Ghatei MA, Bloom SR. Ghrelin enhances appetite and increases food intake in humans. J Clin Endocrinol Metab. 2001 Dec;86(12):5992. doi: 10.1210/jcem.86.12.8111. PMID: 11739476.

7. Asakawa A, Inui A, Kaga T, Yuzuriha H, Nagata T, Ueno N, Makino S, Fujimiya M, Niijima A, Fujino MA, Kasuga M. Ghrelin is an appetite-stimulatory signal from stomach with structural resemblance to motilin. Gastroenterology. 2001 Feb;120(2):337-45. doi: 10.1053/gast.2001.22158. PMID: 11159873.

8. Cummings DE, Purnell JQ, Frayo RS, Schmidova K, Wisse BE, Weigle DS. A preprandial rise in plasma ghrelin levels suggests a role in meal initiation in humans. Diabetes. 2001 Aug;50(8):1714-9. doi: 10.2337/diabetes.50.8.1714. PMID: 11473029.

9. Tschöp M, Wawarta R, Riepl RL, Friedrich S, Bidlingmaier M, Landgraf R, Folwaczny C. Post-prandial decrease of circulating human ghrelin levels. J Endocrinol Invest. 2001 Jun;24(6):RC19-21. doi: 10.1007/BF03351037. PMID: 11434675.

10. Drazen DL, Vahl TP, D'Alessio DA, Seeley RJ, Woods SC. Effects of a fixed meal pattern on ghrelin secretion: evidence for a learned response independent of nutrient status. Endocrinology. 2006 Jan;147(1):23-30. doi: 10.1210/en.20050973. Epub 2005 Sep 22. PMID: 16179409.

11. Garg A. The ongoing saga of obestatin: is it a hormone? J Clin Endocrinol Metab. 2007 Sep;92(9):3396-8. doi: 10.1210/jc.2007-0999. PMID: 17823273.

12. Zhang JV, Ren PG, Avsian-Kretchmer O, Luo CW, Rauch R, Klein C, Hsueh AJ. Obestatin, a peptide encoded by the ghrelin gene, opposes ghrelin's effects on food intake. Science. 2005 Nov 11;310(5750):996-9. doi: 10.1126/science.1117255. PMID: 16284174.

13. Zhu X, Cao Y, Voogd K, Steiner DF. On the processing of proghrelin to ghrelin. J Biol Chem. 2006 Dec 15;281(50):38867-70. doi: 10.1074/jbc.M607955200. Epub 2006 Oct 18. Erratum in: J Biol Chem. 2007 Jan 19;282(3):2124. Voodg, Keith [corrected to Voogd, Keith]. PMID: 17050541.

14. Ozawa A, Cai Y, Lindberg I. Production of bioactive peptides in an in vitro system. Anal Biochem. $2007 \mathrm{Jul}$ 15;366(2):182-9. doi: 10.1016/j.ab.2007.04.020. Epub 2007 Apr 20. PMID: 17540328; PMCID: PMC2128726.

15. Yang J, Brown MS, Liang G, Grishin NV, Goldstein JL. Identification of the acyltransferase that octanoylates ghrelin, an appetite-stimulating peptide hormone. Cell. 2008 Feb 8;132(3):387-96. doi: 10.1016/j.cell.2008.01.017. PMID: 18267071.

16. Hougland JL. Ghrelin octanoylation by ghrelin O-acyltransferase: Unique protein biochemistry underlying metabolic signaling. Biochem Soc Trans. 2019 Feb 28;47(1):169-178. doi: 10.1042/BST20180436. Epub 2019 Jan 9. PMID: 30626708.

17. Ozawa A, Cai Y, Lindberg I. Production of bioactive peptides in an in vitro system. Anal Biochem. $2007 \mathrm{Jul}$ 15;366(2):182-9. doi: 10.1016/j.ab.2007.04.020. Epub 2007 Apr 20. PMID: 17540328; PMCID: PMC2128726.

18. Ferré G, Louet M, Saurel O, Delort B, Czaplicki G, M'Kadmi C, Damian M, Renault P, Cantel S, Gavara L, Demange $P$, Marie J, Fehrentz JA, Floquet N, Milon A, Banères JL. Structure and dynamics of G protein-coupled receptor-bound 
ghrelin reveal the critical role of the octanoyl chain. Proc Natl Acad Sci U S A. 2019 Aug 27;116(35):17525-17530. doi: 10.1073/pnas.1905105116. Epub 2019 Aug 15. PMID: 31416915; PMCID: PMC6717258.

19. Mani BK, Shankar K, Zigman JM. Ghrelin's Relationship to Blood Glucose. Endocrinology. 2019 May 1;160(5):12471261. doi: 10.1210/en.2019-00074. PMID: 30874792; PMCID: PMC6482034.

20. Broglio F, Arvat E, Benso A, Gottero C, Muccioli G, Papotti M, van der Lely AJ, Deghenghi R, Ghigo E. Ghrelin, a natural GH secretagogue produced by the stomach, induces hyperglycemia and reduces insulin secretion in humans. J Clin Endocrinol Metab. 2001 Oct;86(10):5083-6. doi: 10.1210/jcem.86.10.8098. PMID: 11600590.

21. Broglio F, Gottero C, Prodam F, Gauna C, Muccioli G, Papotti M, Abribat T, Van Der Lely AJ, Ghigo E. Non-acylated ghrelin counteracts the metabolic but not the neuroendocrine response to acylated ghrelin in humans. J Clin Endocrinol Metab. 2004 Jun;89(6):3062-5. doi: 10.1210/jc.2003-031964. PMID: 15181099.

22. Reimer MK, Pacini G, Ahrén B. Dose-dependent inhibition by ghrelin of insulin secretion in the mouse. Endocrinology. 2003 Mar;144(3):916-21. doi: 10.1210/en.2002-220819. PMID: 12586768.

23. Dezaki K, Hosoda H, Kakei M, Hashiguchi S, Watanabe M, Kangawa K, Yada T. Endogenous ghrelin in pancreatic islets restricts insulin release by attenuating $\mathrm{Ca}+$ signaling in beta-cells: implication in the glycemic control in rodents. Diabetes. 2004 Dec;53(12):3142-51. doi: 10.2337/diabetes.53.12.3142. PMID: 15561944.

24. Salehi A, Dornonville de la Cour C, Håkanson R, Lundquist I. Effects of ghrelin on insulin and glucagon secretion: a study of isolated pancreatic islets and intact mice. Regul Pept. 2004 May 15;118(3):143-50. doi:

10.1016/j.regpep.2003.12.001. PMID: 15003830.

25. Qader SS, Lundquist I, Ekelund M, Håkanson R, Salehi A. Ghrelin activates neuronal constitutive nitric oxide synthase in pancreatic islet cells while inhibiting insulin release and stimulating glucagon release. Regul Pept. 2005 May 15;128(1):51-6. doi: 10.1016/j.regpep.2004.12.018. PMID: 15721487.

26. Soriano-Guillén L, Barrios V, Martos G, Chowen JA, Campos-Barros A, Argente J. Effect of oral glucose administration on ghrelin levels in obese children. Eur J Endocrinol. 2004 Jul;151(1):119-21. doi: 10.1530/eje.0.1510119. PMID: 15248831.

27. Martos-Moreno GA, Barrios V, Soriano-Guillén L, Argente J. Relationship between adiponectin levels, acylated ghrelin levels, and short-term body mass index changes in children with diabetes mellitus type 1 at diagnosis and after insulin therapy. Eur J Endocrinol. 2006 Nov;155(5):757-61. doi: 10.1530/eje.1.02273. PMID: 17062893.

28. De Vriese C, Gregoire F, Lema-Kisoka R, Waelbroeck M, Robberecht P, Delporte C. Ghrelin degradation by serum and tissue homogenates: identification of the cleavage sites. Endocrinology. 2004 Nov;145(11):4997-5005. doi: 10.1210/en.2004-0569. Epub 2004 Jul 15. PMID: 15256494.

29. Barrett, A. J. and Rawlings, N. D. Introduction: metallopeptidases and their clans. Handbook of Proteolytic Enzymes. 2004 1:231-268, Elsevier Academic Press, London

30. Becker AB, Roth RA. An unusual active site identified in a family of zinc metalloendopeptidases. Proc Natl Acad Sci U S A. 1992 May 1;89(9):3835-9. doi: 10.1073/pnas.89.9.3835. PMID: 1570301; PMCID: PMC525585.

31. MIRSKY IA, BROH-KAHN RH. The inactivation of insulin by tissue extracts; the distribution and properties of insulin inactivating extracts. Arch Biochem. 1949 Jan;20(1):1-9. PMID: 18104389.

32. Baskin FK, Duckworth WC, Kitabchi AE. Sites of cleavage of glucagon by insulin-glucagon protease. Biochem Biophys Res Commun. 1975 Nov 3;67(1):163-9. doi: 10.1016/0006-291x(75)90297-1. PMID: 1201016.

33. Gehm BD, Rosner MR. Regulation of insulin, epidermal growth factor, and transforming growth factor-alpha levels by growth factor-degrading enzymes. Endocrinology. 1991 Mar;128(3):1603-10. doi: 10.1210/endo-128-3-1603. PMID: 1847863.

34. Becker AB, Roth RA. Insulysin and pitrilysin: insulin-degrading enzymes of mammals and bacteria. Methods Enzymol. 1995;248:693-703. doi: 10.1016/0076-6879(95)48046-3. PMID: 7674956.

35. Shen Y, Joachimiak A, Rosner MR, Tang WJ. Structures of human insulin-degrading enzyme reveal a new substrate recognition mechanism. Nature. 2006 Oct 19;443(7113):870-4. doi: 10.1038/nature05143. Epub 2006 Oct 11. PMID: 17051221; PMCID: PMC3366509.

36. Kurochkin IV. Amyloidogenic determinant as a substrate recognition motif of insulin-degrading enzyme. FEBS Lett. 1998 May 8;427(2):153-6. doi: 10.1016/s0014-5793(98)00422-0. PMID: 9607302.

37. Stefanidis L, Fusco ND, Cooper SE, Smith-Carpenter JE, Alper BJ. Molecular Determinants of Substrate Specificity in Human Insulin-Degrading Enzyme. Biochemistry. 2018 Aug 14;57(32):4903-4914. doi:

10.1021/acs.biochem.8b00474. Epub 2018 Jul 25. PMID: 30004674. 
38. Adames N, Blundell K, Ashby MN, Boone C. Role of yeast insulin-degrading enzyme homologs in propheromone processing and bud site selection. Science. 1995 Oct 20;270(5235):464-7. doi: 10.1126/science.270.5235.464. PMID: 7569998.

39. Michaelis S, Herskowitz I. The a-factor pheromone of Saccharomyces cerevisiae is essential for mating. Mol Cell Biol. 1988 Mar;8(3):1309-18. doi: 10.1128/mcb.8.3.1309. PMID: 3285180; PMCID: PMC363277.

40. Powers S, Michaelis S, Broek D, Santa Anna S, Field J, Herskowitz I, Wigler M. RAM, a gene of yeast required for a functional modification of RAS proteins and for production of mating pheromone a-factor. Cell. 1986 Nov 7;47(3):413-22. doi: 10.1016/0092-8674(86)90598-2. PMID: 3533274.

41. Michaelis S, Barrowman J. Biogenesis of the Saccharomyces cerevisiae pheromone a-factor, from yeast mating to human disease. Microbiol Mol Biol Rev. 2012 Sep;76(3):626-51. doi: 10.1128/MMBR.00010-12. PMID: 22933563; PMCID: PMC3429625.

42. Kim S, Lapham AN, Freedman CG, Reed TL, Schmidt WK. Yeast as a tractable genetic system for functional studies of the insulin-degrading enzyme. J Biol Chem. 2005 Jul 29;280(30):27481-90. doi: 10.1074/jbc.M414192200. Epub 2005 Jun 8. PMID: 15944156.

43. Alper BJ, Nienow TE, Schmidt WK. A common genetic system for functional studies of pitrilysin and related M16A proteases. Biochem J. 2006 Aug 15;398(1):145-52. doi: 10.1042/BJ20060311. PMID: 16722821; PMCID: PMC1525005.

44. Phillips, JE. Characterization of Ste23p and atPreP, Members of the biomedically significant M16 metalloprotease subfamily. Undergraduate Honors Thesis, University of Georgia, 2007.

45. Considine KL, Stefanidis L, Grozinger KG, Audie J, Alper BJ. Efficient synthesis of $\alpha$-fluoromethylhistidine dihydrochloride and demonstration of its efficacy as a glutathione S-transferase inhibitor. Bioorg Med Chem Lett. 2017 Mar 15;27(6):1335-1340. doi: 10.1016/j.bmcl.2017.02.024. Epub 2017 Feb 14. PMID: 28228363.

46. Bradford MM. A rapid and sensitive method for the quantitation of microgram quantities of protein utilizing the principle of protein-dye binding. Anal Biochem. 1976 May 7;72:248-54. doi: 10.1006/abio.1976.9999. PMID: 942051.

47. Ivancic VA, Krasinski CA, Zheng Q, Meservier RJ, Spratt DE, Lazo ND. Enzyme kinetics from circular dichroism of insulin reveals mechanistic insights into the regulation of insulin-degrading enzyme. Biosci Rep. 2018 Nov 7;38(6):BSR20181416. doi: 10.1042/BSR20181416. PMID: 30305381; PMCID: PMC6239264.

48. Lazo ND, Downing DT. Circular dichroism of model peptides emulating the amphipathic alpha-helical regions of intermediate filaments. Biochemistry. 1997 Mar 4;36(9):2559-65. doi: 10.1021/bi963061b. PMID: 9054562.

49. Kirschner RJ, Goldberg AL. A high molecular weight metalloendoprotease from the cytosol of mammalian cells. J Biol Chem. 1983 Jan 25;258(2):967-76. PMID: 6401723.

50. Candiano G, Bruschi M, Musante L, Santucci L, Ghiggeri GM, Carnemolla B, Orecchia P, Zardi L, Righetti PG. Blue silver: a very sensitive colloidal Coomassie G-250 staining for proteome analysis. Electrophoresis. 2004 May;25(9):1327-33. doi: 10.1002/elps.200305844. PMID: 15174055.

51. Johnson GD, Ahn K. Development of an internally quenched fluorescent substrate selective for endothelinconverting enzyme-1. Anal Biochem. 2000 Nov 1;286(1):112-8. doi: 10.1006/abio.2000.4772. PMID: 11038281.

52. Sharma SK, Chorell E, Wittung-Stafshede P. Insulin-degrading enzyme is activated by the C-terminus of $\alpha$-synuclein. Biochem Biophys Res Commun. 2015 Oct 16;466(2):192-5. doi: 10.1016/j.bbrc.2015.09.002. Epub 2015 Sep 4. PMID: 26343304. 


\section{Figure legends}

Figure 1. Ghrelin proteolysis by insulin-degrading enzyme (IDE). A. SDS-PAGE analysis of synthetic acyl ghrelin degradation following $1 \mathrm{hr}$ coincubation with IDE, a catalytically inactive IDE mutant (IDE E111Q), neprilysin (NEP), glutathione S-transferase (GST), or IDE pretreated with ethylenediaminetetraacetate (IDE+EDTA) as a metal chelating agent and metalloprotease inhibitor. The migratory position of ghrelin prior to digestion is indicated with a black arrowhead (4) Gel load amounts correspond with initial input of $2.5 \mu \mathrm{g}$ octanoylated synthetic ghrelin and $0.15 \mu \mathrm{g}$ recombinant protein to the initial condition of the enzymatic assay mixture. The gel was stained with colloidal Coomassie Brilliant Blue G-250. Molecular weights of intact, full-length peptides and proteins are as follows: octanoylated ghrelin, 3371 Da; IDE and IDE E111Q, 110 kDa; NEP, 86 kDa; GST, 26 kDa. B. Densitometric analysis inclusive data presented in Fig. 1A was performed using BioRad Image Lab Version 6 densitometry software (2 experimental replicates).

Figure 2. Kinetics of ghrelin degradation by IDE. A. SDS-PAGE analysis of ghrelin proteolysis following coincubation with IDE, IDE-E111Q catalytic mutant, and neprilysin (NEP). Reactions were terminated the timepoint indicated. B. Densitometric analysis inclusive data shown in Fig. 2A was performed by peak integration using BioRad Image Lab Version 6 densitometry software ( $\geq 2$ experimental replicates). The rate of ghrelin hydrolysis by IDE from 0 to 5 minutes was $7.1 \pm 1.1$ (standard deviation) $\mathrm{nmol} \mathrm{min}^{-1} \mathrm{mg}^{-1}$.

Figure 3. IDE-mediated ghrelin cleavage sites. A. HPLC chromatograms revealing IDE-mediated ghrelin cleavage over time. Chromatographic traces for each timepoint are shown. B. Inset from chromatogram shown in $3 A$, revealing peak elution profiles from $\sim 11.5-14 \mathrm{~min}$. Peaks corresponding with single-site cleavage at Q14/R15, Q13/Q14, and Q10/R11 are predominant. C. Ghrelin cleavage products over time. Relative quantities of intact peptide and cleavage products are inferred from peak integration of data above D. Schematic representation of IDE-mediated ghrelin cleavage sites. Predominant early cleavage sites are indicated with black arrows $(\downarrow)$.

Figure 4. Design, synthesis and proteolysis of a ghrelin derivative quenched-fluorogenic peptide. A. Representation of the Mca-QRVQQRKESKK(Dnp)-OH peptide (FRET ghrelin; Mca: 7-methoxycoumarin-3-carboxylic acid, Dnp: 2,4dinitrophenyl) made for and used in this study. Positions of IDE mediated cut sites are indicated with dashed lines and grey arrows $(\downarrow)$. B. Reverse-phase (C18) HPLC chromatogram for isolation of the Mca-QRVQQRKESKK(Dnp)-OH peptide following solid-phase synthesis and cleavage. C. Confirmation of Mca-QRVQQRKESKK(Dnp)-OH synthesis and purification by MALDI-TOF. D. Kinetic analysis of Mca-QRVQQRKESKK(Dnp)-OH cleavage by real time fluorescence assay (excitation: $325 \pm 25 \mathrm{~nm}$, emission: $420 \pm 25 \mathrm{~nm}$ ). The Mca-QRVQQRKESKK(Dnp)-OH peptide alone (mock; deep blue) does not exhibit significant change in fluorescence over the time course, and is largely overlapped by the NEP, and NEP+EDTA datasets. E. Identification of FRET ghrelin cleavage fragments by MALDI-TOF following proteolysis of McaQRVQQRKESKK(Dnp)-OH by IDE. Major cleavage fragments Mca-QRVQQ-OH (m/z 860) and Mca-QRVQ-OH (m/z 732) are identified. The full-length FRET peptide $(\mathrm{m} / \mathrm{z}$ 1780) remains detectable following incomplete hydrolysis. F. Proteolysis of bradykinin derivative commercial Substrate $V$ (Mca-RPPGFSAFK-Dnp) confirms catalytic activity of both IDE and NEP.

Figure 5. Circular dichroism structural analysis of IDE substrates. A. Circular dichroism (CD) spectrum of acyl ghrelin in $30 \%$ TFE (2,2,2-trifluoroethanol). B. Acyl ghrelin in $50 \mathrm{mM}$ Tris, pH 7.3. C. Insulin and insulin degrading enzyme (IDE) in $30 \%$ TFE. Substrate to enzyme ratio is 100:1. D. Insulin and IDE in $50 \mathrm{mM}$ Tris, pH 7.3. Substrate to enzyme ratio is 100:1. The intensity of insulin's helical dichroic signal at $222 \mathrm{~nm}$ decreases with digestion time. All CD spectra were recorded at $37^{\circ} \mathrm{C}$. 
Figure 1. Ghrelin proteolysis by insulin-degrading enzyme (IDE)

A.

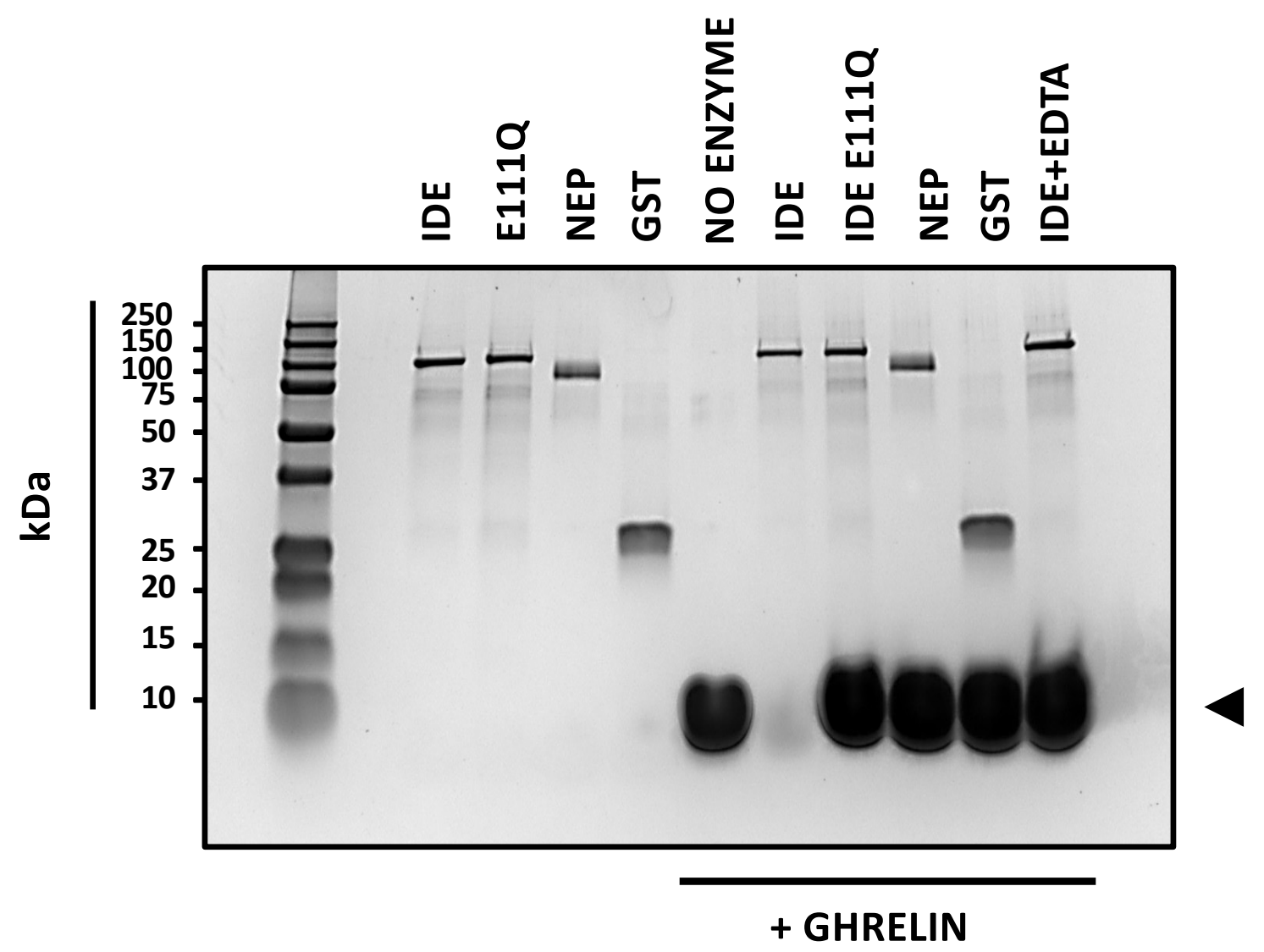

B.

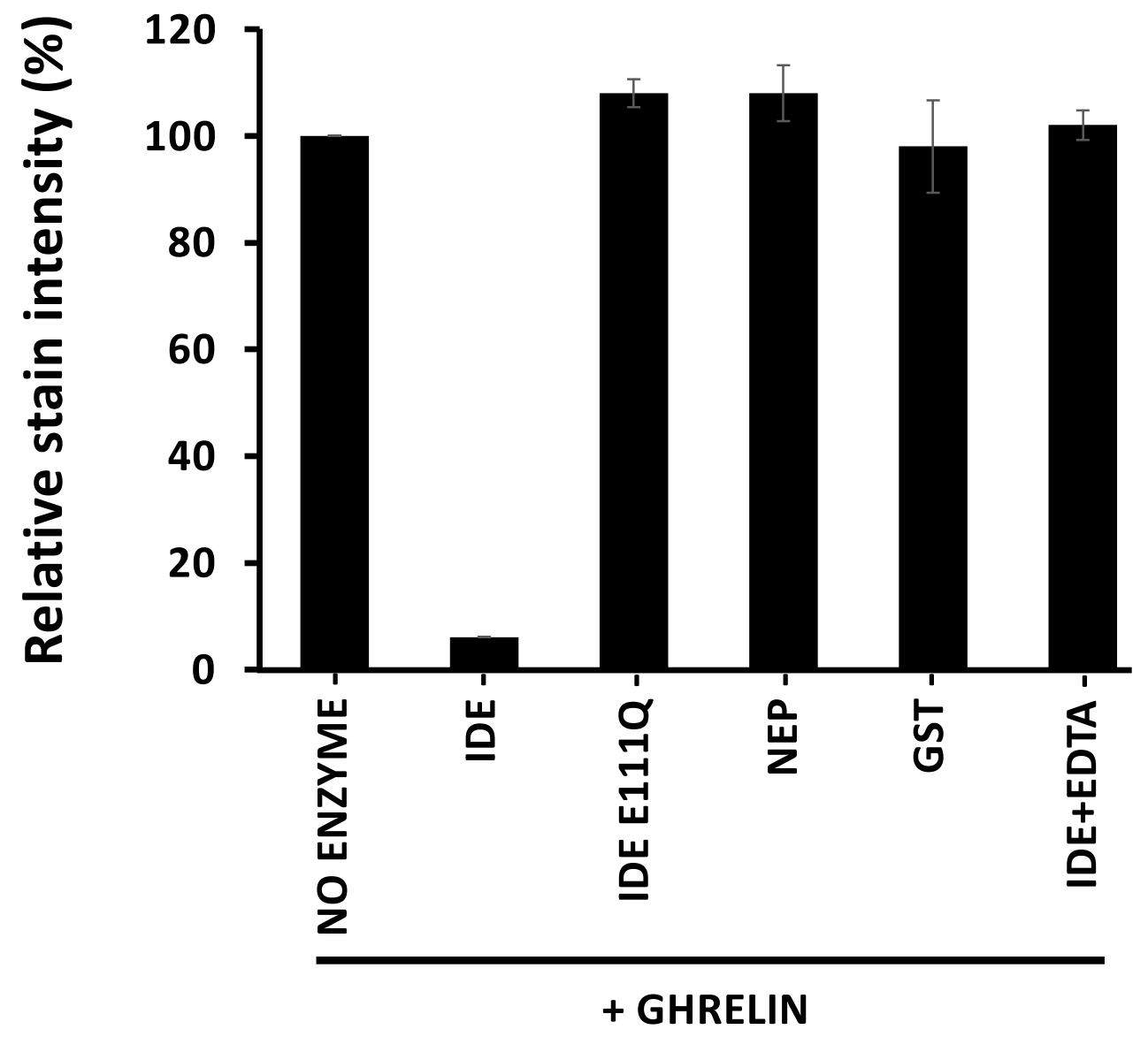


Figure 2. Kinetics of ghrelin degradation

A.

ENZYME

GHRELIN

ENZYME + GHRELIN

$\square \quad 0125102030 \mathrm{~min}$.

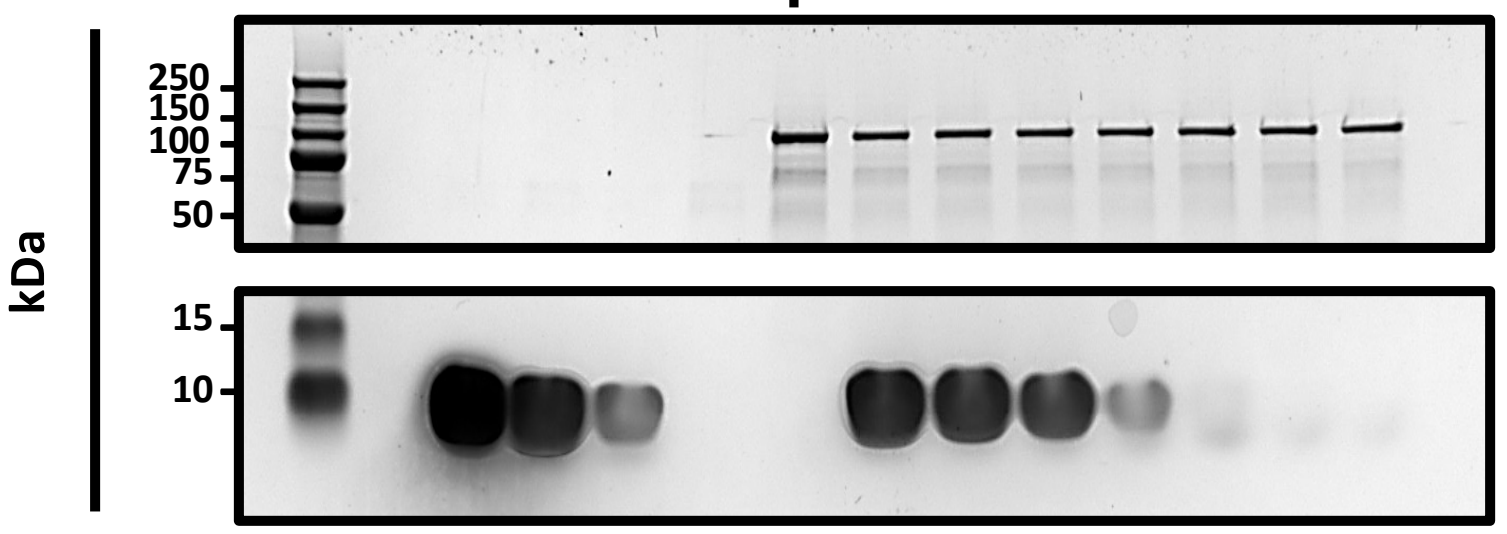

IDE

GHRELIN

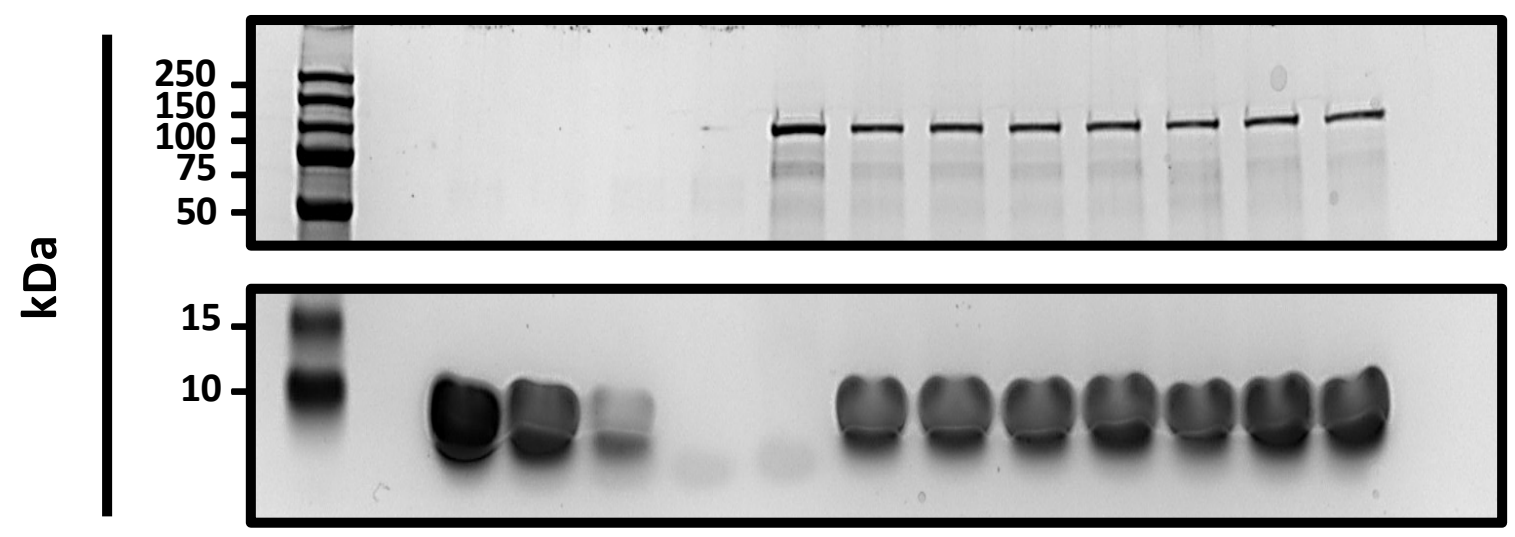

IDE E111Q

GHRELIN

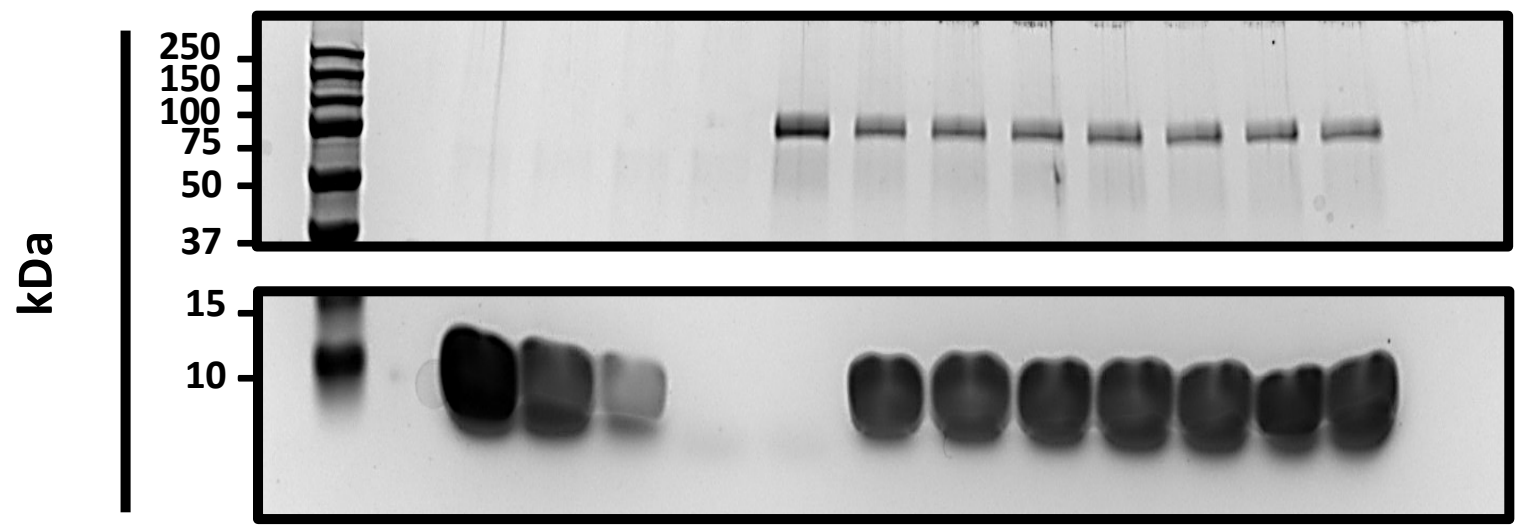

NEP

GHRELIN 
Figure 2. Kinetics of ghrelin degradation

B.

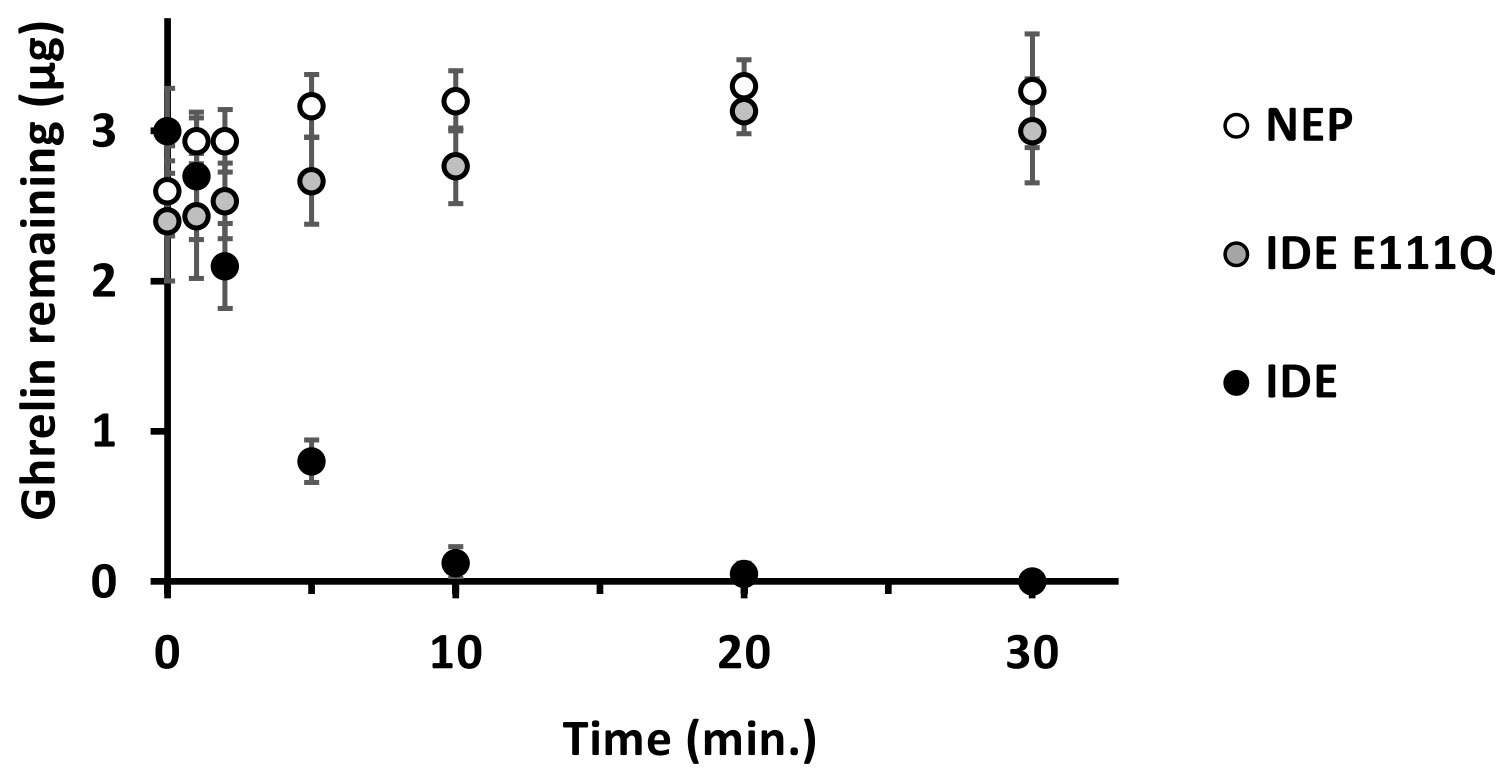


Figure 3. IDE-mediated ghrelin cleavage sites

A.

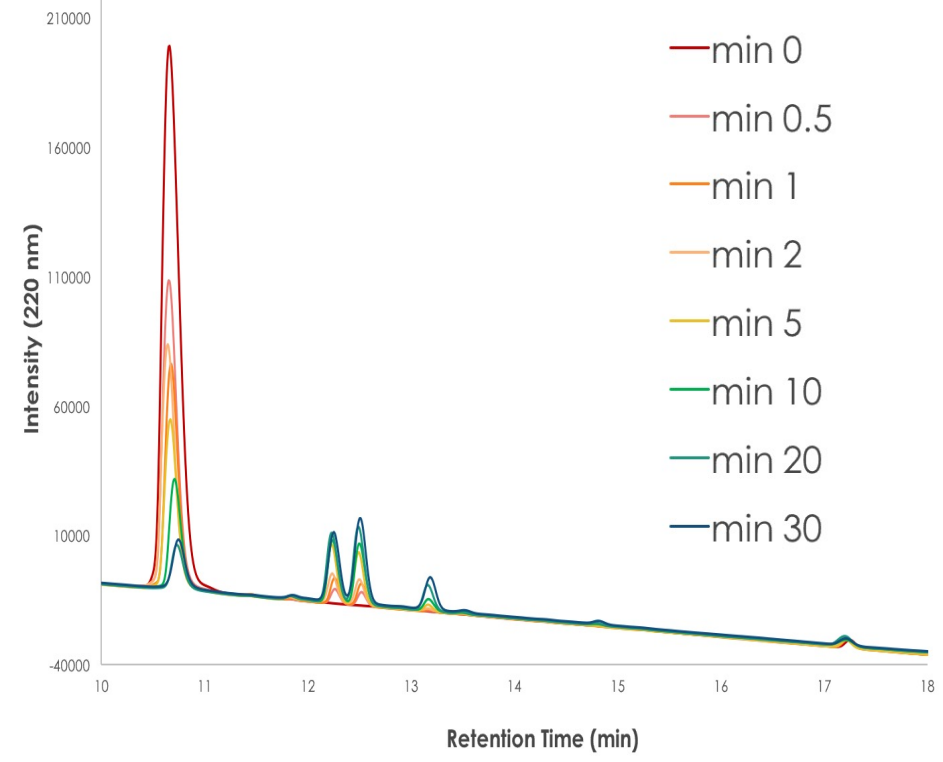

B.

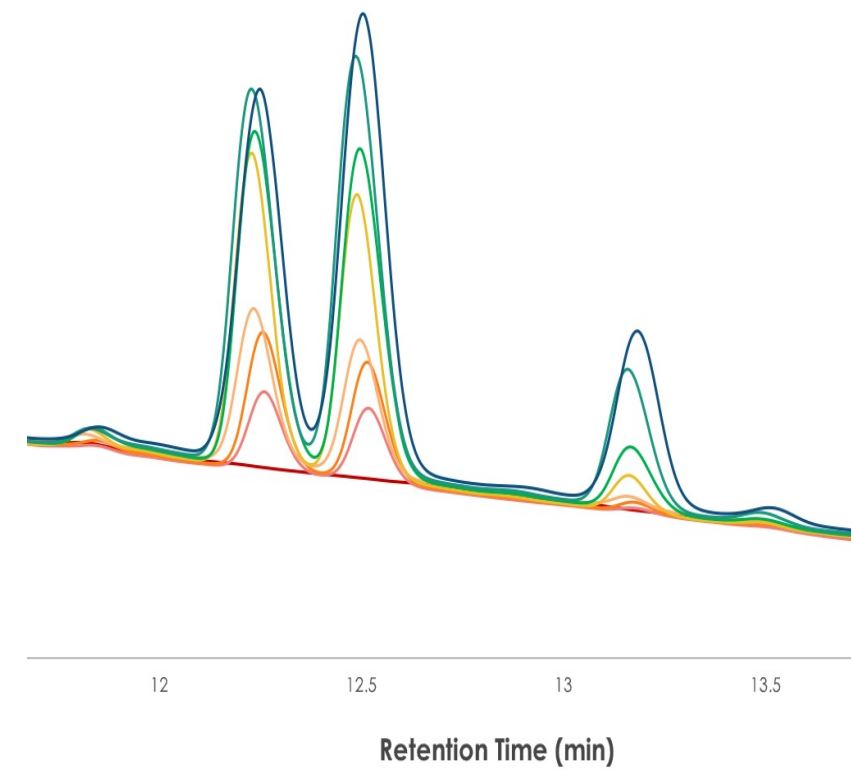

C.

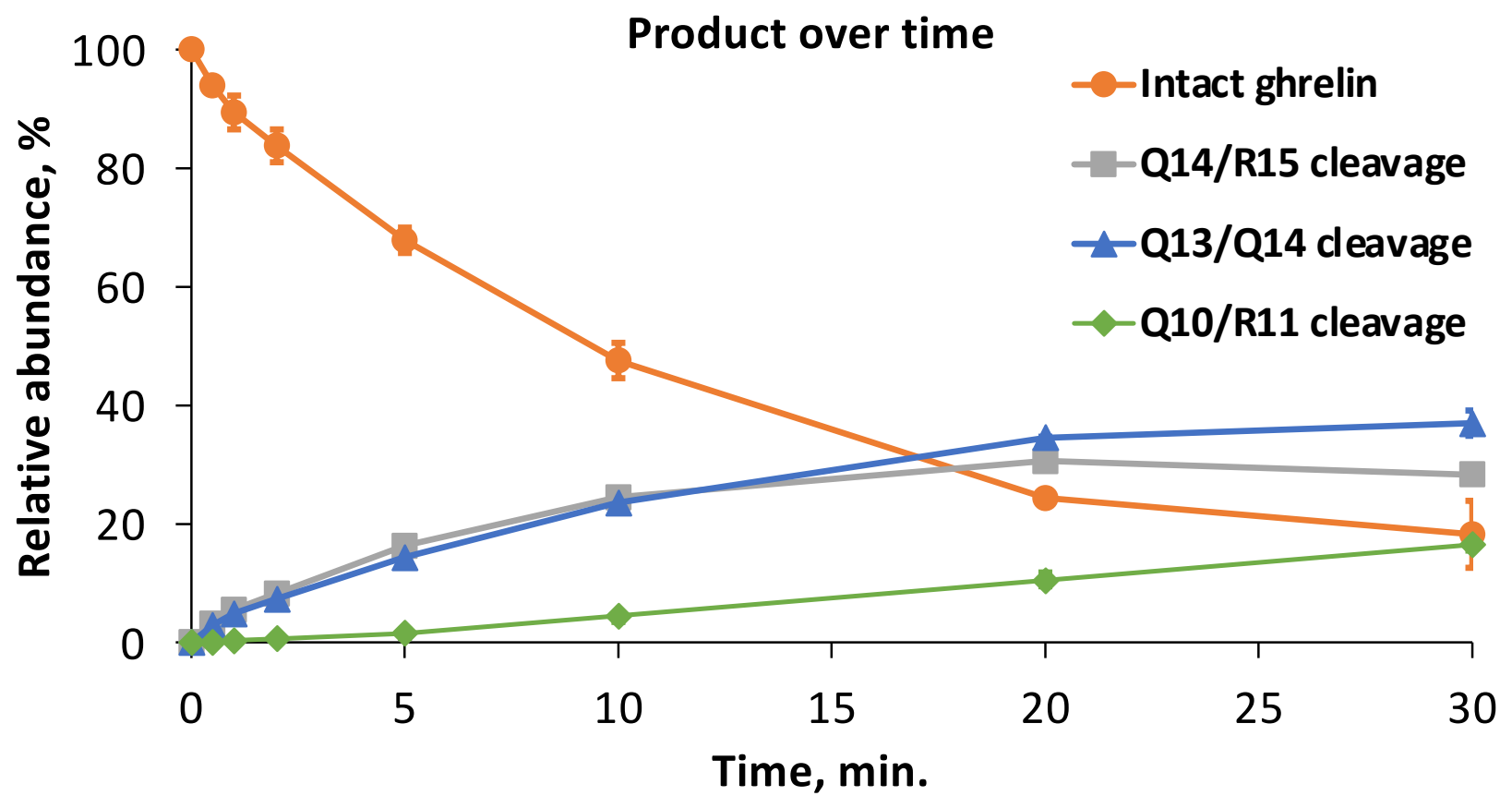

D.<smiles>CCCCCCCC(=O)OC</smiles>

$\mathrm{H}_{2} \mathrm{~N}-{ }^{1}$ GS-S-FLSPEHQRVQQRKESKKPPAKLQPR ${ }_{\uparrow}^{28}$

$\uparrow$ Cleavage site 
Figure 4. Design, synthesis and proteolysis of ghrelin derivative quenchedfluorogenic peptide

A.

FRET ghrelin

Exact Mass 1781.84, Molecular Weight 1782.89

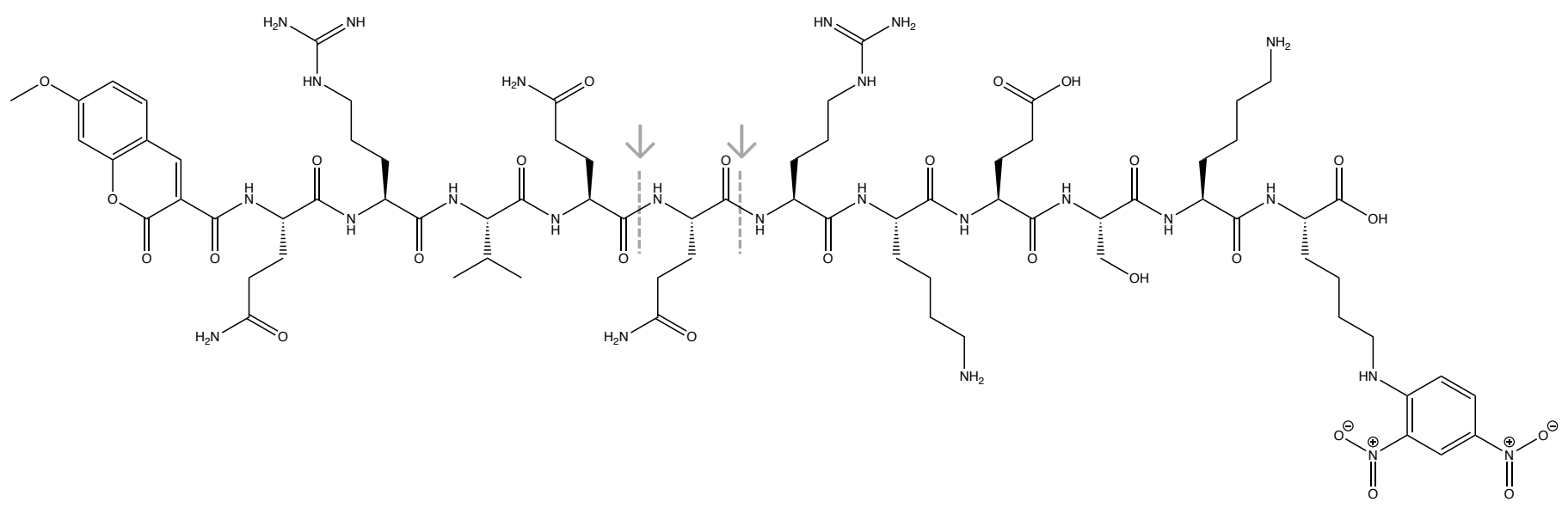

B.

C.

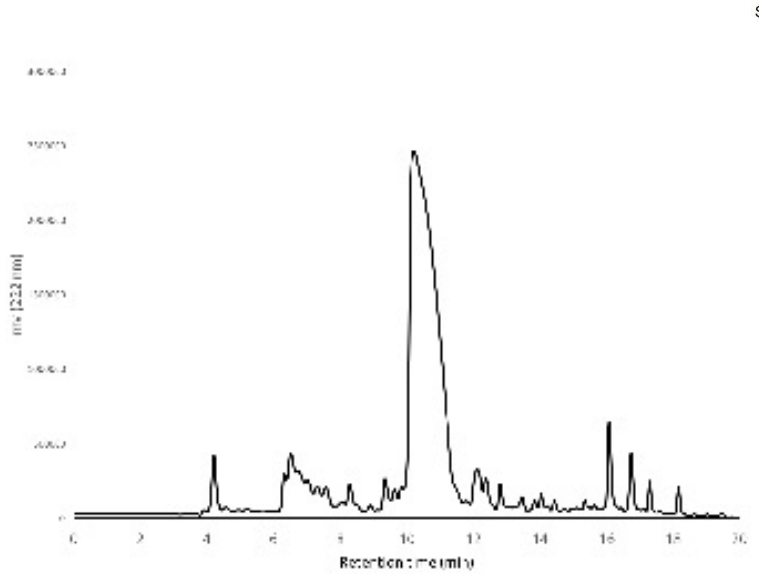

Shimadzu Biotech Axima Confidence 2.9.3.20110624: Mode Reflectron, Power: 50, Blanked, P.Ext. @ 550 (bin 58)

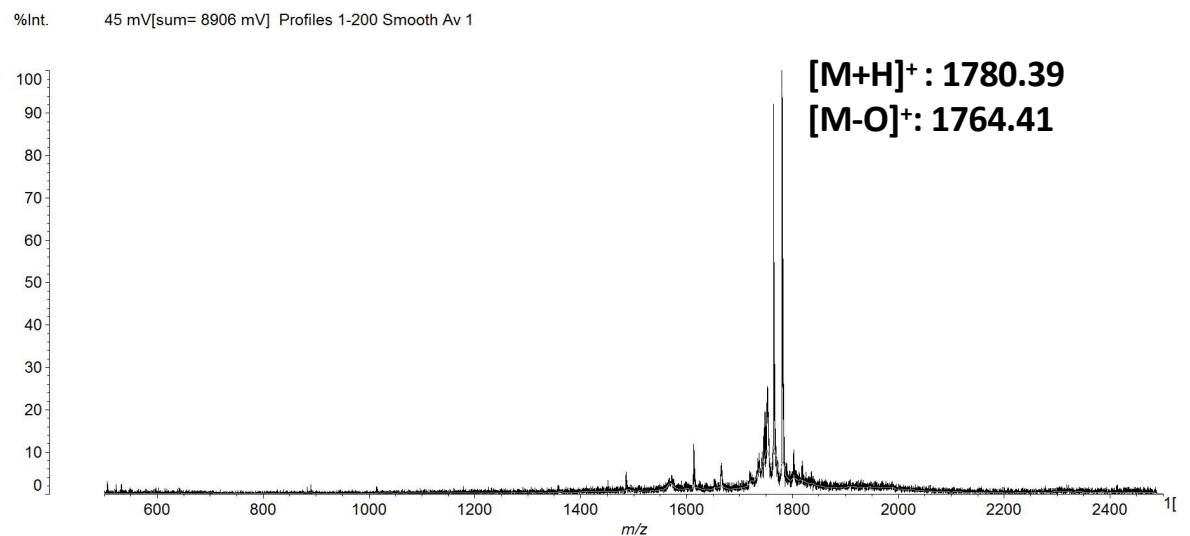

D.

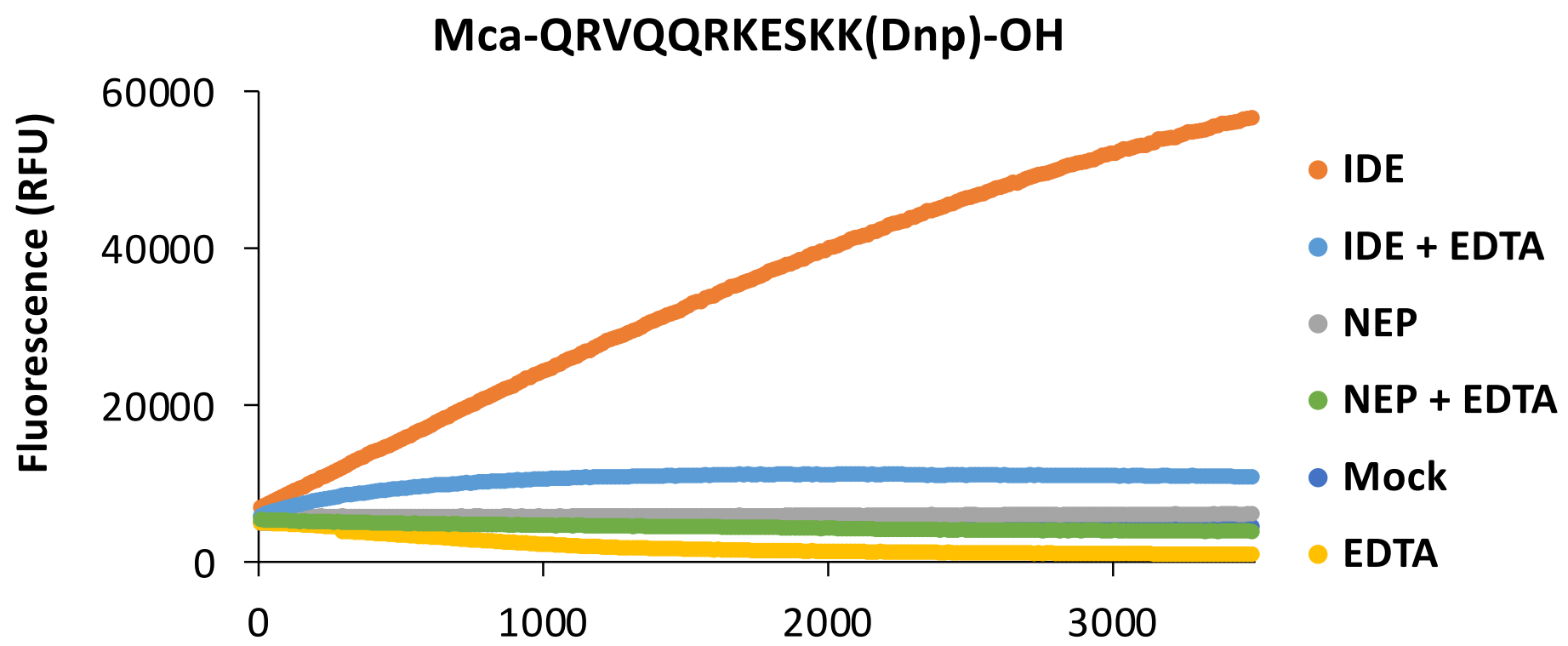

Time, $s$ 
Figure 4. Design, synthesis and proteolysis of ghrelin derivative quenchedfluorogenic peptide

E.

Shimadzu Biotech Axima Confidence 2.9.3.20110624: Mode Reflectron, Power: 65, Blanked, P.Ext. @ 2300 (bin 99)

\%Int. $\quad 1895 \mathrm{mV}[\mathrm{sum}=379051 \mathrm{mV}]$ Profiles $1-200$ Smooth Av 1

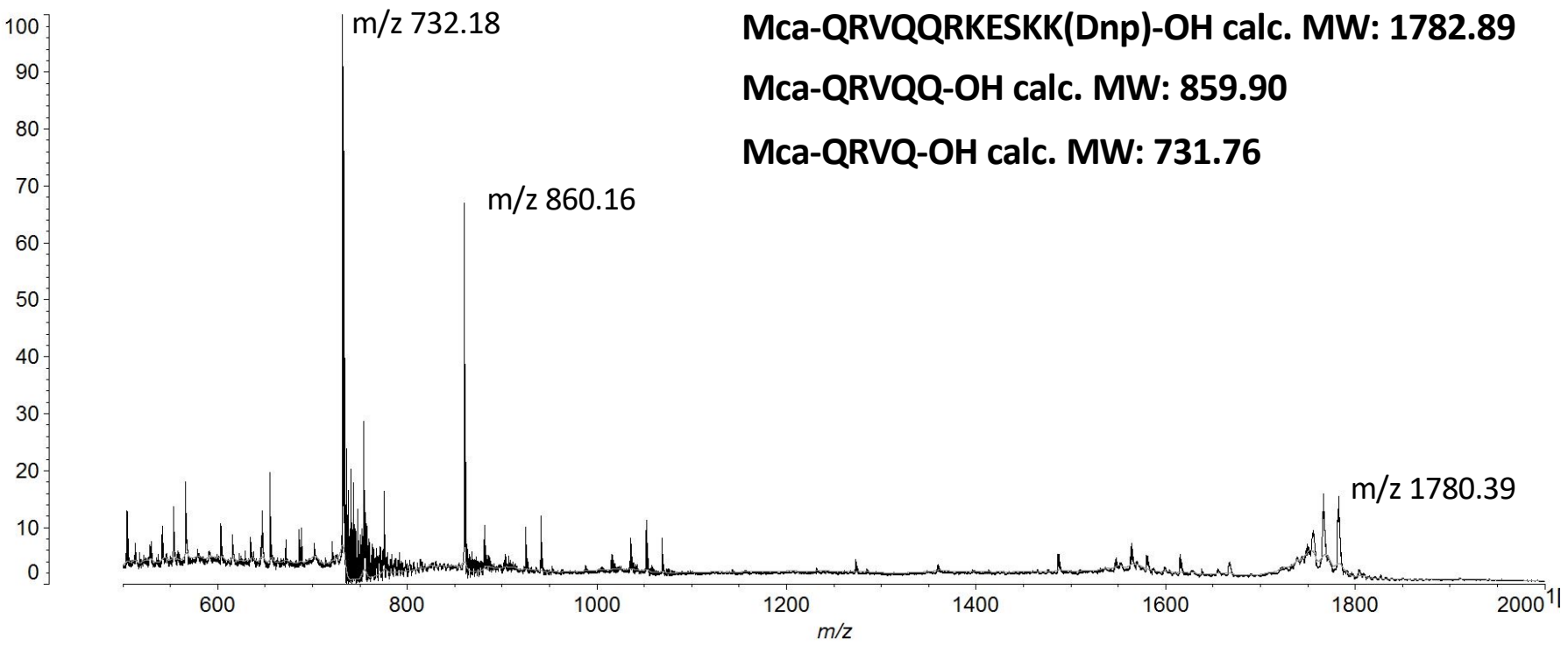

F.

Substrate V (Mca-RPPGFSAFK-Dnp)

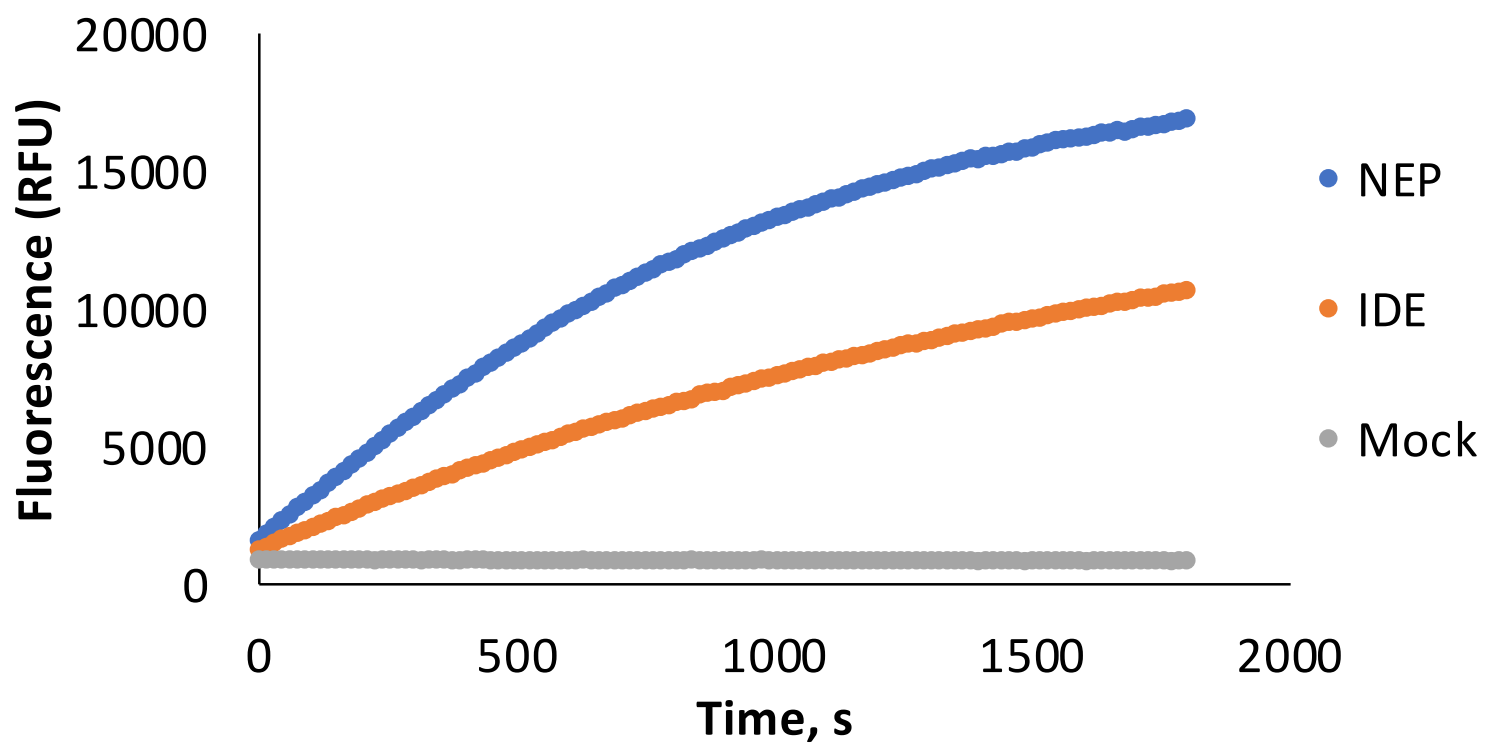


Figure 5. Circular dichroism structural analysis of IDE substrates

A.

ghrelin (30\% TFE)

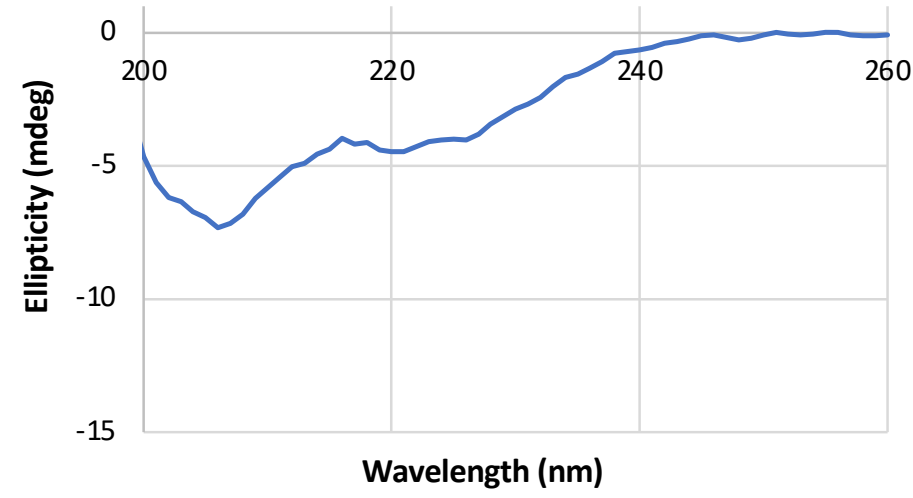

C.

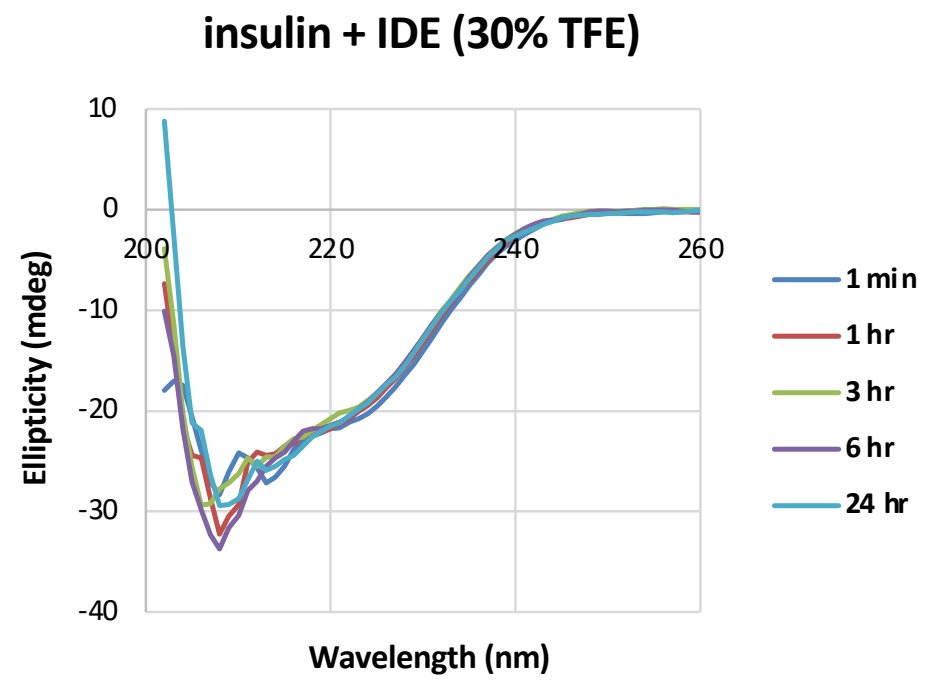

B.

ghrelin (50 mM Tris pH 7.3)

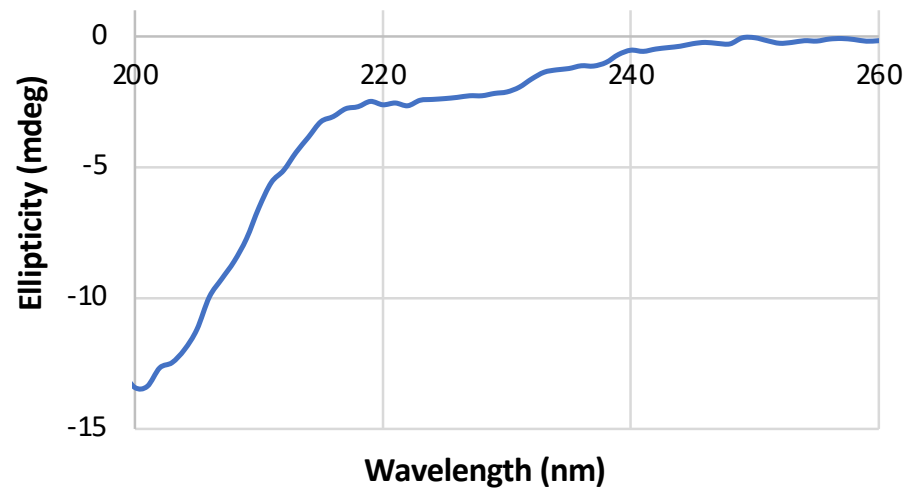

D. insulin + IDE (50 mM Tris pH 7.3)

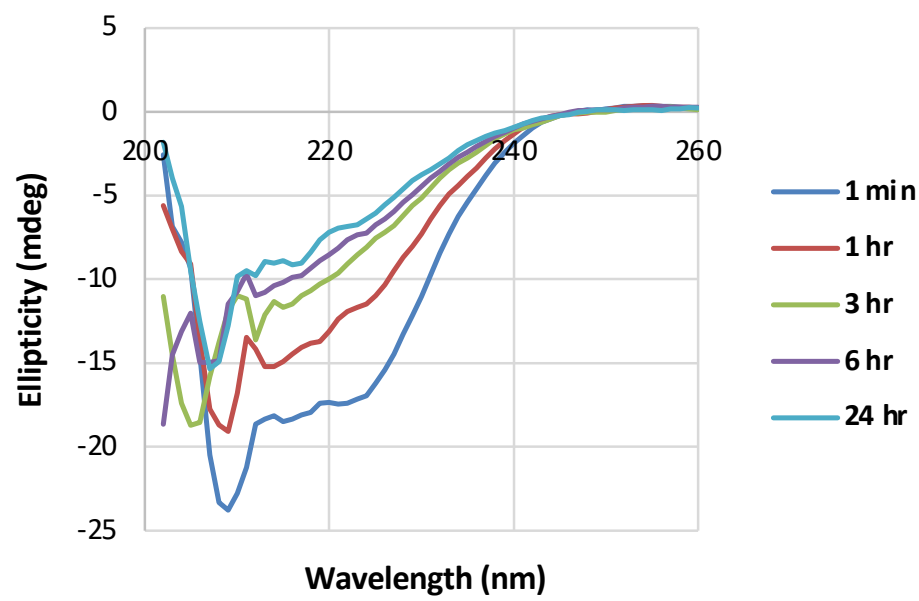

